\title{
Lethal and Sublethal Effects of UV-B/pH Synergism on Common Frog Embryos
}

\author{
MAARIT PAHKALA, ${ }^{\circledR} \rrbracket$ KATJA RÄSÄNEN, ${ }^{*}$ ANSSI LAURILA, ${ }^{*}$ ULF JOHANSON, $\neq$ \\ LARS OLOF BJÖRN, $\neq$ AND JUHA MERILÄ*†
}

*Department of Population Biology, Evolutionary Biology Centre, Uppsala University, Norbyvägen $18 \mathrm{~d}$, SE-752 36, Sweden

† Section of Population Biology, Department of Ecology and Systematics, University of Helsinki, P.O. Box 17, FIN-00014 Helsinki, Finland

‡Department of Plant Biology, Lund University, P.O. Box 117, SE-22100 Lund, Sweden

\begin{abstract}
Although the negative effects of ultraviolet-B (UV-B) radiation on the development of many amphibian species have been demonstrated, some species-such as the common frog (Rana temporaria)-seem to be tolerant of $U V-B$ radiation. The amount of $U V-B$ radiation received is likely to vary among populations of the same species, but little is known about geographic variation in UV-B tolerance. Similarly, although UV-B radiation can have synergistic effects with other stressors, no studies have focused on geographic variation of these effects on amphibians. We investigated the synergistic effects of UV-B radiation and low $p H$ on batchability and early development of R. temporaria embryos in a factorial laboratory experiment with animals originating from southern and northern Sweden. Newly fertilized eggs were exposed to three different $U V$ - $B$ treatments (no UV-B [control], $1.254 \mathrm{k} / \mathrm{J} / \mathrm{m}^{2}$ [normal] and $1.584 \mathrm{k} / \mathrm{J} / \mathrm{m}^{2}$ [26\% enbanced]) and two $\mathrm{pH}$ treatments (4.5 [low] and 7.6 [neutral]). Ultraviolet-B radiation in combination with low pH lead to markedly (approximately 50\%) reduced survival rates and increased (approximately 30\%) frequency of developmental anomalies in the northern but not in the southern population. The UV-B-exposed embryos hatched at smaller size in the southern population, whereas low pH reduced hatchling size in both populations. In both populations and $p H$ treatments, embryos in the normal $U V-B$ treatment developed significantly faster than embryos in the enbanced or control UV-B treatments. No interaction between $p H$ and $U V-B$ on developmental rates or batchling size was detected. The results demonstrate-contrary to earlier belief-that $\mathrm{R}$. temporaria embryos are not insensitive to increased levels of $U V-B$ radiation. The lethal effects of $U V-B$ radiation may, however, become manifested only in combination with other stressors, such as low pH, and the effects of this synergism may differ among different populations of the same species.
\end{abstract}

Efectos Letales y Subletales del Sinergismo B-UV/pH en Embriones de Rana Común

Resumen: Aunque se han demostrado los efectos negativos de la radiación B-ultravioleta (B-UV) sobre el desarrollo de muchas especies de anfibios, algunas especies-tal como la rana común (Rana temporaria)parecen ser tolerantes a la radiación $B-U V$. La cantidad de radiación $B-U V$ recibida varia entre poblaciones de la misma especie, pero poco se sabe sobre la variación geográfica en cuanto a la tolerancia a B-UV. De manera similar, aunque la radiación B-UV puede tener efectos sinérgicos con otros factores estresantes, ningún estudio se ha centrado en la variación geográfica de estos efectos en anfibios. Investigamos los efectos sinérgicos de la radiación B-UV y pH bajo sobre la eclosión y el desarrollo temprano de embriones de R. temporaria en un experimento de laboratorio factorial con animales provenientes del sur y del norte de Suecia. Se expusieron buevos recién fertilizados a tres tratamientos diferentes de UV-B (sin B-UV [control], $1.254 \mathrm{k} / \mathrm{J} / \mathrm{m}^{2}$ [normal] y $1.584 \mathrm{k} / \mathrm{J} / \mathrm{m}^{2}$ [26\% más de lo normal]) y dos tratamientos de pH (4.5 [bajo] y 7.6 [neutral]). La radiación B-UV combinada con $\mathrm{pH}$ bajo condujo a tasas de supervivencia significativamente bajas (aproximadamente 50\%) e incrementó (aproximadamente 30\%) la frecuencia de anormalidades en el desarrollo en la

\Current address: Department of Biology, University of Oulu, P.O. Box 3000, FIN-90014 Oulu, Finland, email maarit.pabkala@oulu.fi Paper submitted December 8, 2000; revised manuscript accepted September 26, 2001. 
población del norte, pero no en la del sur. Los embriones expuestos a B-UV eclosionaron con menor tamaño en la población sureña, mientras que el pH bajo redujo el tamaño al eclosionar en las dos poblaciones. En ambas poblaciones y tratamientos de $\mathrm{pH}$ los embriones en tratamiento de B-UV normal se desarrollaron significativamente más rápido que los embriones en los tratamientos control y por arriba de lo normal. No se detectó ninguna interacción entre $\mathrm{pH}$ y B-UV y las tasas de desarrollo o tamaño al eclosionar. Los resultados demuestran-contrariamente a lo que se pensaba-que los embriones de R. temporaria no son insensibles al incremento de niveles de radiación B-UV. Sin embargo, los efectos letales de la radiación B-UV pueden manifestarse solo en combinación con otros estresantes, tal como pH bajo, y los efectos de este sinergismo pueden variar entre diferentes poblaciones de la misma especie.

\section{Introduction}

Recent reports indicate that many amphibian species have exhibited population declines and range reductions (Pechmann et al. 1991; Wake 1991; Pechmann \& Wilbur 1994; Alford \& Richards 1999; Houlahan et al. 2000). Several anthropogenic factors are thought to contribute to these declines, including habitat destruction, climate changes, chemical pollutants, introduced exotic species, and increased levels of ultraviolet-B (UV-B, 280-315 nm) radiation (Alford \& Richards 1999). As for the last possibility, several researchers have found higher mortality rates among amphibian eggs exposed to ambient levels of UV-B radiation than among those sheltered from UV-B (e.g., Ankley et al. 1998; Broomhall et al. 2000; Kiesecker et al. 2001; for a review of earlier literature see Blaustein et al. 1998). However, amphibian species differ in their sensitivity to UV-B radiation (Blaustein et al. 1994, 1999; Ovaska et al. 1997; Anzalone et al. 1998; Lizana \& Pedraza 1999; Langhelle et al. 1999; Broomhall et al. 2000), and some species, such as the common frog (Rana temporaria), are considered tolerant of even high levels of UV-B radiation (Cummins et al. 1999; Langhelle et al. 1999; Hofer \& Mokri 2000; Merilä et al. 2000a; Pahkala et al. 2000; but see Pahkala et al. 2001).

However, the responses of developing amphibians to UV-B radiation can depend on other abiotic or biotic stressors that are present. Polycyclic aromatic hydrocarbons (Hatch \& Burton 1998; Walker et al. 1998; Monson et al. 1999), other chemical contaminants (Ankley et al. 1998; Zaga et al. 1998), pathogens (Kiesecker \& Blaustein 1995; Kiesecker et al. 2001), and low pH (Long et al. 1995; Hatch \& Blaustein 2000) amplify the negative effects of UV-B radiation exposure to amphibian embryos. For instance, Long et al. (1995) found that the negative effects of UV-B on survival of Rana pipiens eggs were expressed only under low $\mathrm{pH}$ conditions. The synergistic effects of UV-B and low $\mathrm{pH}$ could be a particular concern in Scandinavia and northern America, where large areas have been exposed to acid rain (Brodin 1993; Arctic Monitoring Assessment Program 1998). Environmental acidification reduces the amount of dissolved organic carbon (DOC), thus enhancing the pene- tration of UV-B into the water column and increasing UV-B radiation stress (Schindler et al. 1996; Lean 1998). Consequently, studies of the synergistic effects of low $\mathrm{pH}$ and UV-B radiation on the development of species considered UV-B tolerant can be illuminating.

Because the amount of UV-B radiation received differs in different populations of the same species (e.g., Belden et al. 2000; Merilä et al. 2000b), it is possible that populations inhabiting areas differing in their UV-B regimes also have diverged genetically in their resistance to UV-B radiation (Blaustein et al. 1994; Williamson et al. 1997, Corn 1998; Belden et al. 2000). Furthermore, if the synergistic effects of UV-B radiation and other abiotic stress factors (e.g., low $\mathrm{pH}$, temperature) are important determinants of UV-B stress tolerance, then populations subject to different environmental conditions may also differ in their tolerance of UV-B radiation. Several researchers have compared UV-B radiation tolerance among amphibian populations in field experiments conducted in different localities (Blaustein et al. 1994, 1999; Kiesecker \& Blaustein 1995; Corn 1998). These studies are useful for comparing UV-B radiation tolerance within the environments where the investigations were conducted (Blaustein et al. 1998), but they may tell little about the possible intrinsic differences among the populations because the comparisons were not conducted under uniform environmental conditions. Few studies have compared several amphibian populations under uniform conditions. Recently, Belden et al. (2000) found in a laboratory experiment that two populations of long-toed salamander (Ambystoma macrodactylum) differed in larval sensitivity to UV-B radiation. To know whether spatial variability in intrinsic tolerance to UV-B radiation occurs in amphibians, more studies are needed that compare the tolerance to UV-B radiation of multiple populations under common environmental conditions.

Apart from increasing mortality rates, UV-B radiation may have sublethal effects on amphibians in terms of altered behavior (Zaga et al. 1998; Belden et al. 2000; Blaustein et al. 2000; Hatch \& Blaustein 2000; Kats et al. 2000), developmental anomalies (Worrest \& Kimeldorf, 1975, 1976; Grant \& Licht 1995; Kiesecker \& Blaustein 1995; Langhelle et al. 1999; Merilä et al. 2000a; Pahkala 
et al. 2000), and larval growth and development (Grant \& Licht 1995; Bruggeman et al. 1998; Belden et al. 2000; Smith et al. 2000; Pahkala et al. 2001). Ultraviolet-B radiation may also have a negative effect on embryonic growth and development (size and age at hatching) of amphibians (Hatch \& Burton 1998; Merilä et al. 2000a; Pahkala et al. 2000), which may have consequences for an individual's later performance. Small size at hatching may have negative effects on survival and growth, because smaller larvae are more vulnerable to predators (Caldwell et al. 1980; Wilbur et al. 1983), are less efficient in exploiting resources (Steinwascher 1979; Travis 1984), and may be smaller at metamorphosis (reviewed by Kaplan 1998). Small size at metamorphosis can lead to delayed breeding, reduced fecundity, and lower mating success (Kaplan \& Salthe 1979; Howard 1980; Smith 1987; Semlitsch et al. 1988; Berven 1990). Consequently, investigations of sublethal effects of UV-B radiation on amphibian embryonic stages may reveal important mechanisms affecting later performance.

\section{Methods}

\section{Study Species and Populations}

Rana temporaria is found throughout most of the western Palearctic up to $71^{\circ} \mathrm{N}$ (Gasc et al. 1997). It breeds in various kinds of water bodies in early spring and tends to avoid waters with low pH (Strijbosch 1979; Beebee 1983; Laurila 1998). Eggs are usually laid in shallow water with extensive surface contact, which allows for faster development but also exposes the eggs to UV-B radiation. Depending on water temperature, the eggs usually hatch within 2 weeks after fertilization (J. M. \& A. L., personal observation).

We studied the effects of UV-B radiation and $\mathrm{pH}$ on $R$. temporaria embryos in a laboratory experiment in April-June 1999. The experiment was conducted with two populations, one originating from southern Sweden (Lund: lat. $55^{\circ} 40^{\prime} \mathrm{N}$, long. $13^{\circ} 30^{\prime} \mathrm{E}$; elevation $19 \mathrm{~m} ; \mathrm{pH} \approx$ 7) and one from northern Sweden (Umeå; lat. $63^{\circ} 50^{\prime} \mathrm{N}$, long. $20^{\circ} 25^{\prime} \mathrm{E}$; elevation $64 \mathrm{~m} ; \mathrm{pH} \approx 7$ ).

We collected 10 adult males and females from the southern population and 4 adult males and females from the northern population and brought them to a laboratory in Uppsala. Each male was then artificially mated with one female following the procedure of Berger et al. 1994, resulting in 10 and 4 families (clutches) per population, respectively. Artificial mating ensured that all offspring in a given clutch were full siblings (multiple paternity occurs in nature; Laurila \& Seppä 1998) and that the eggs had no prior exposure to low $\mathrm{pH}$ or UV-B radiation. Apparently damaged eggs were discarded prior to experimentation. After fertilization, the eggs $(<2$ hours old) were divided into batches of 30-50 and placed in experimental vessels $(0.28 \mathrm{~L}$; polystyrene; $5.5 \times 10 \mathrm{~cm})$ about $4.5 \mathrm{~cm}$ below the water surface.

\section{Experimental Design}

We conducted the experiment in a constant-temperature room $\left(15^{\circ} \mathrm{C}\right.$, corresponding to the typical spring temperature in Scandinavia) in three aquarium systems, each of which consisted of two experimental aquaria $(120 \times 120 \times 25 \mathrm{~cm}$; about $320 \mathrm{~L})$ positioned one on top of the other with a reservoir tank $(90 \times 90 \times 35 \mathrm{~cm}$; about $280 \mathrm{~L}$ ) below them. Each aquarium system was filled with reconstituted soft water, which was continuously circulated through a cooling unit (flow rate: $3 \mathrm{~L} /$ minute) to reduce temperature fluctuations caused by the greenhouse lamps.

The experiment consisted of the fully factorial combination of three UV-B and two $\mathrm{pH}$ treatments, with each family replicated three times within each treatment combination. Replicates were randomly placed in the aquaria so that within each aquarium the total number of vessels per treatment was equal. To control for possible variation of irradiance in the aquarium, the placement of vessels within them was changed randomly each day.

The experimental vessels containing the eggs were filled with reconstituted soft water and placed on top of a plastic netting situated $5 \mathrm{~cm}$ below the water surface. There was no exchange of water between the experimental vessels and the surrounding water circulating in the aquarium systems. As a direct consequence of the radiation from the greenhouse lamps, there were regular daily temperature variations $\left(10-17^{\circ} \mathrm{C}\right)$ in the aquaria. The average daytime (0800-1700 hours) water temperature during the experiments was $15.2 \pm 0.10^{\circ} \mathrm{C}$ for the southern and $15.6 \pm 0.01^{\circ} \mathrm{C}$ for the northern population. These temperatures are within the range encountered in both populations in the wild (A.T. Laugen \& J.M., unpublished data). The average temperatures in different UV-B treatments differed slightly $\left(15.9 \pm 0.11^{\circ} \mathrm{C}\right.$, $15.1 \pm 0.11^{\circ} \mathrm{C}$, and $15.1 \pm 0.09^{\circ} \mathrm{C}$ for control, normal, and high UV-B treatments, respectively) but significantly $\left(F_{2,101}=34.9, p<0.001\right)$. Therefore, mean temperature in each experimental unit was included in the analyses as a covariate to control for possible temperature effects.

\section{UV-B Treatments}

We divided the UV-B treatments into six blocks, two for each UV-B treatment, over the three aquarium systems; thus, each system contained two blocks. The daily photoperiod was 17 hours light and 7 hours dark, and the UV-B exposure periods occurred around noon (11001400), mimicking the situation in nature (Josefsson \& Karlsson 1997). We used a computer model (Björn \& Murphy 1985; Björn \& Teramura 1993) to calculate the 
daily irradiance of UV-B in Uppsala on 24 April (the normal breeding time of $R$. temporaria) and the daily increase in UV-B radiation that would follow from $15 \%$ ozone depletion under clear-sky conditions resulting in 26\% enhanced UV-B levels. The DNA-weighted daily UV-B exposures were 1.254 and $1.584 \mathrm{~kJ} / \mathrm{m}^{2}$ for normal and enhanced UV-B, respectively. The UV-B exposures from Uppsala were used as an intermediate reference point because Uppsala is situated in the middle of Sweden halfway between the two localities. We adjusted the levels of UV-B by regulating daily irradiation regimes in the following way: (1) normal UV-B (irradiation time, 2 hours 17 minutes/day); (2) high UV-B (2 hours 53 minutes/day); and (3) control ( 2 hours 17 minutes/day), where UV-B and UV-C were blocked with a Mylar filter (0.10 mm, Erik S. Ekman, Stockholm). The UV-B radiation for each aquarium was provided by four fluorescent tubes (120 cm, 40W, Q-PANEL, UV-B 313, Cleveland, Ohio) preburned for 100 hours to give a stable output. In each aquarium, the four fluorescent tubes were placed $50 \mathrm{~cm}$ above water level and uniformly parallel (40 cm between each lamp) to one another. The midsection (approximately $40 \mathrm{~cm}$ ) of the two central tubes was covered with aluminum foil to obtain an even radiation distribution within the aquarium.

For the normal and high UV-B treatments the radiation passed through a cellulose diacetate filter $(0.13 \mathrm{~mm}$, Courtaulds, Derby, United Kingdom) to cut off ultraviolet-C radiation (UV-C $<280 \mathrm{~nm}$ ). Details of filter properties follow those of Pahkala et al. (2000). Filters were placed about $25 \mathrm{~cm}$ above the water level to allow air circulation beneath them and were changed every second week to ensure that their properties remained homogenous during the experiment.

To ensure sufficient background light for normal functioning of light-dependent DNA damage-repair mechanisms (Zhao \& Mu 1998), two 400-W greenhouse lamps (Powerstar HQI-BT 400 W/D, OSRAM, 350-700 nm) were fitted over each of the six aquaria. The amount of radiated light (white light, including UV-A) was measured with a LI-COR light meter (Li-Cor, Lincoln, Nebraska) that had a quantum sensor, giving an irradiance of 320 $\mu \mathrm{mol} / \mathrm{m}^{2} / \mathrm{second}$.

\section{Water Preparation and $\mathrm{pH}$ Treatments}

The two pH levels corresponded to naturally low (4.5) and neutral (7.6) $\mathrm{pH}$ in the typical breeding localities of this species (Leuven et al. 1986; Aston et al. 1987). Throughout the experiment we used reconstituted soft water consisting of $\mathrm{NaHCO}_{3}(48 \mathrm{mg} / \mathrm{L}), \mathrm{CaSO}_{4} \times 2 \mathrm{H}_{2} \mathrm{O}$ $(30 \mathrm{mg} / \mathrm{L}), \mathrm{MgSO}_{4} \times 7 \mathrm{H}_{2} \mathrm{O}(61.37 \mathrm{mg} / \mathrm{L})$, and $\mathrm{KCl}(2$ $\mathrm{mg} / \mathrm{L}$; American Public Health Association 1985). Water for both $\mathrm{pH}$ treatments was prepared in 80-L storage tanks, adjusted with 1 or $0.1 \mathrm{M} \mathrm{H}_{2} \mathrm{SO}_{4}$, and stabilized for 48 hours before use. The $\mathrm{pH}$ levels were monitored with a portable Hanna HI 9025 pH meter equipped with an Orion Ross sure-flow 8172BN electrode. We changed the water in each vessel daily and measured $\mathrm{pH}$ randomly from a few vessels. The $\mathrm{pH}$ remained stable between water changes.

\section{Response Variables}

The response variables we measured were survival, frequency of developmental anomalies, development time, and hatchling size. The experiment was terminated when 10 larvae in a given vessel had reached stage 25 (Gosner 1960), at which point survival (recorded as the proportion of eggs surviving until the end of the experiment) and the number of seemingly abnormal individuals (flexure of the tail or edema) were recorded. Larvae with visible developmental anomalies were excluded from the survival estimates because their future survival was highly unlikely (Beattie et al. 1992). The post-hatch larvae were not fed because the experiment was termi-

Table 1. Mixed-model nested analyses of covariance of survival rate in response to UV-B and pH treatments in two Rana temporaria populations.*

\begin{tabular}{|c|c|c|c|c|c|c|c|c|}
\hline $\begin{array}{l}\text { Random } \\
\text { family } \\
\text { residual }\end{array}$ & $\begin{array}{l}0.0055 \\
0.0647\end{array}$ & $\begin{array}{l}0.0048 \\
0.0079\end{array}$ & $\begin{array}{l}1.13 \\
8.17\end{array}$ & $\begin{array}{l}0.1285 \\
0.0001\end{array}$ & $\begin{array}{l}0.0072 \\
0.0377\end{array}$ & $\begin{array}{l}0.0080 \\
0.0076\end{array}$ & $\begin{array}{l}0.90 \\
4.95\end{array}$ & $\begin{array}{l}0.1829 \\
0.0001\end{array}$ \\
\hline & ndf & ddf & $F$ & $p$ & ndf & ddf & $F$ & $p$ \\
\hline UV-B & 2 & 135 & 0.84 & 0.4333 & 2 & 49.6 & 9.71 & 0.0003 \\
\hline $\mathrm{pH}$ & 1 & 134 & 8.0 & 0.0054 & 1 & 49.4 & 34.42 & 0.0001 \\
\hline $\mathrm{UV}-\mathrm{B} \times \mathrm{pH}$ & 2 & 135 & 1.92 & 0.1512 & 2 & 49.6 & 10.04 & 0.0002 \\
\hline temperature & 1 & 134 & 0.54 & 0.4645 & 1 & 49.3 & 0.35 & 0.5553 \\
\hline
\end{tabular}

*Tests were performed with arcsine-square-root-transformed data. Abbreviations: ndf, numerator degrees of freedom; ddf, denominator degrees of freedom. 

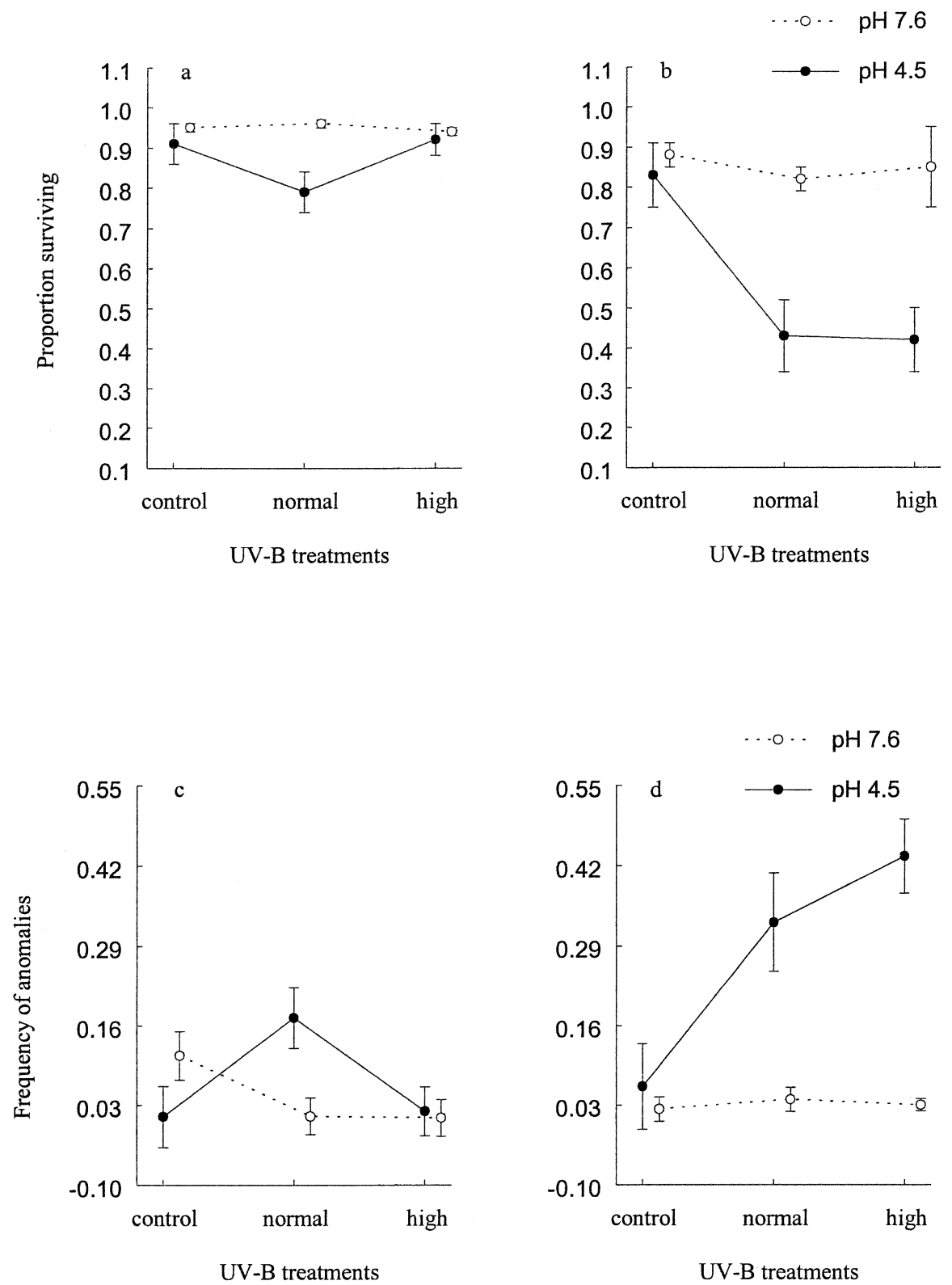

Figure 1. Survival and frequency of developmental anomalies of Rana temporaria embryos in different $U V-B$ and $p H$ treatments: (a) survival of southern and (b) northern embryos and frequency of developmental anomalies among (c) southern and (d) northern embryos. Values are least square means ( $\pm S E$ ) from models presented in Tables 1 and 2.

nated before the feeding stage (cf. Gosner 1960). Development time was determined as the number of days from the start of the experiment until the 10 larvae reached stage 25 . The larvae from each replicate were preserved in $10 \%$ formalin for later measurement. Hatchling size was determined from five preserved larvae from each replicate as total length of the larvae from tip of the nose to tip of the tail under a stereomicroscope (to the nearest $0.1 \mathrm{~mm}$ ). All measurements were taken blind with respect to the experimental treatments.

\section{Statistical Analyses}

We used mixed-model analysis of covariance (ANCOVA) to investigate the effects of UV-B and $\mathrm{pH}$ treatments on the measured variables, as implemented in PROC MIXED in the SAS statistical package (SAS Institute 1996). Because our experimental design made predictions about the effects of population and $\mathrm{pH}$ and UV-B treatments, these factors were treated as fixed effects in the models, whereas family (nested under population) was considered a random effect (Zar 1996). Although family effects are given in the tables, they are not commented on in the results because this term was included solely to control for nonindependence of data points within a family. Family interactions (family $\times \mathrm{pH}$ and family $\times \mathrm{UV}$-B) were excluded from further analyses because none was significant. Temperature was included as a covariate to control for temperature variation. To keep the interpretation simple, separate ANCOVAs were first run for both 
Table 2. Mixed-model nested analyses of covariance of the frequency of developmental anomalies in response to UV-B and pH treatments in two Rana temporaria populations.*

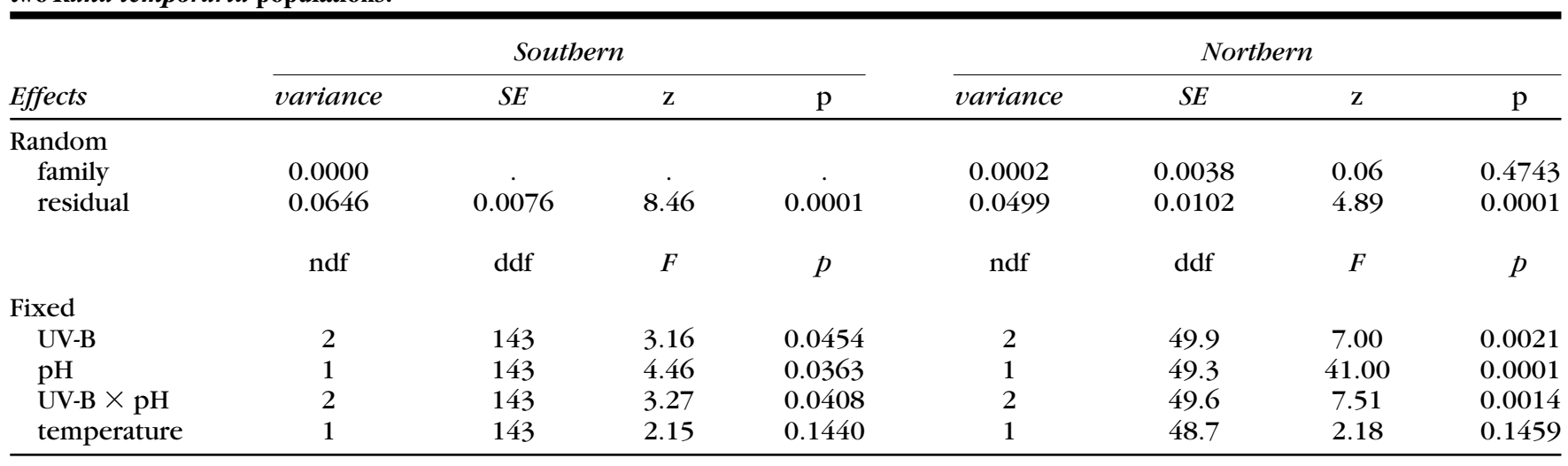

${ }^{*}$ Tests were performed with arcsine-square-root-transformed data. Abbreviations: ndf, numerator degrees of freedom; ddf, denominator degrees of freedom.

populations. This procedure was followed by a common ANCOVA for both populations to extract the betweenpopulation effects. To obtain correct degrees of freedom for the effects in the models, we used the Satterthwaite procedure, as implemented in PROC MIXED of the SAS statistical package (Littell et al. 1996). For analyses of hatchling size, we used the mean value of the hatchlings in each replicate as a unit. Before statistical testing, both survival and anomaly estimates were arcsine-square-root transformed to normalize their distributions. All statistical analyses were performed with 6.12 version of the SAS statistical package (SAS Institute 1996).

\section{Results}

\section{Survival}

Low $\mathrm{pH}$ reduced embryonic survival rates in the southern population, but there was no evidence of UV-B treatment or synergistic effect of $\mathrm{pH}$ and UV-B on survival rates (Table 1; Fig. 1a). In contrast, both UV-B and $\mathrm{pH}$ had a significant effect on embryonic survival rates in the northern population. A significant interaction between UV-B and $\mathrm{pH}$ in the northern population (Table 1; Fig. 1b) showed that the negative effects of normal and high UV-B treatments on survival were seen only in the low pH treatment (Table 1; Fig. 1b), indicating that the two stressors acted in a synergistic fashion. A combined analysis of the two populations confirmed that the population differences seen in the separate analyses were significant (population $\times \mathrm{UV}-\mathrm{B} \times \mathrm{pH}: F_{2,186}=5.54, p=$ 0.0046 ; population $\times$ UV-B: $F_{2,186}=7.22, p=0.001$; population $\times \mathrm{pH}: F_{1,185}=5.74, p=0.0175$ ). Furthermore, survival rate was significantly lower for the northern than for the southern embryos (Fig. 1a \& 1b; population: $F_{1,13.1}=25.59, p=0.0002$ ), but this was due largely to the strong effects of UV-B radiation and interactions between UV-B and $\mathrm{pH}$ the northern population.

\section{Developmental Anomalies}

Analyses of the frequency of developmental anomalies generally concurred with the results of the survival analyses: significant main effects of UV-B and $\mathrm{pH}$ were found in both populations, but these were much stronger in the northern than in the southern population (Table 2; Fig. 1c \& 1d). Again, synergistic effects of UV-B and pH in the northern population were manifested by a significant UV-B $\times \mathrm{pH}$ interaction (Table 2), which was due to the proportionally higher increase in the frequency of anomalies in the normal and high UV-B treatments in low-pH conditions than with the control treatment (Fig. 1d). Nevertheless, there was also a significant interaction between UV-B and $\mathrm{pH}$ in the southern population owing to an increased frequency of anomalies in the normal UV-B treatment under low-pH conditions (Fig. 1c). A combined analysis of the two populations confirmed, however, that their responses to UV-B and $\mathrm{pH}$ treatments were significantly different (population $X$ UV-B $\times$ pH: $F_{2,196}=4.97, p=0.0078$ ), suggesting higher sensitivity of northern embryos to combined effects of UV-B and pH on embryonic development (Fig. $1 \mathrm{c}$ and $1 \mathrm{~d})$.

\section{Development Time}

Effects of UV-B and $\mathrm{pH}$ treatments on development time were similar in both populations (Fig. $2 \mathrm{a} \& 2 \mathrm{~b}$ ). Low $\mathrm{pH}$ prolonged the development time significantly in both populations, but the normal UV-B treatment had the opposite effect (Table 3; Fig. 2a \& 2b). Embryos experiencing a normal UV-B regime developed faster than those experiencing high or no UV-B radiation (Table 3; Fig. 2a $\& 2 \mathrm{~b}$ ). No significant interaction between UV-B and $\mathrm{pH}$ was detected in either of the populations (Table 3), and a combined analysis of both populations confirmed the similarity of the treatment effects in both populations (population $\times \mathrm{pH} \times$ UV-B: $F_{2,208}=1.40, p=0.25$ ). How- 


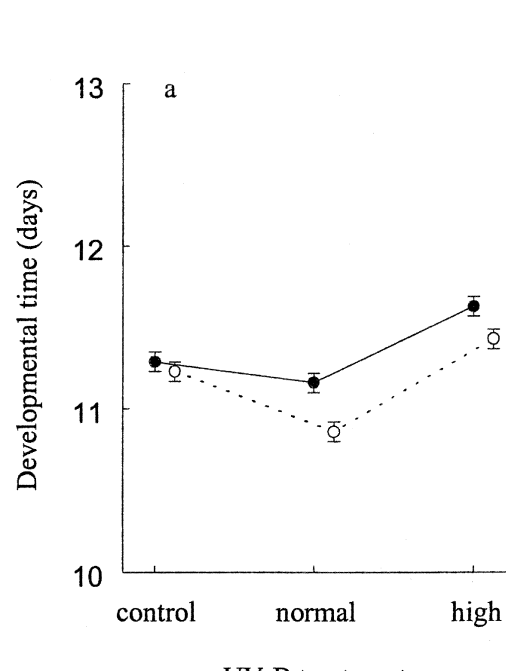

UV-B treatments

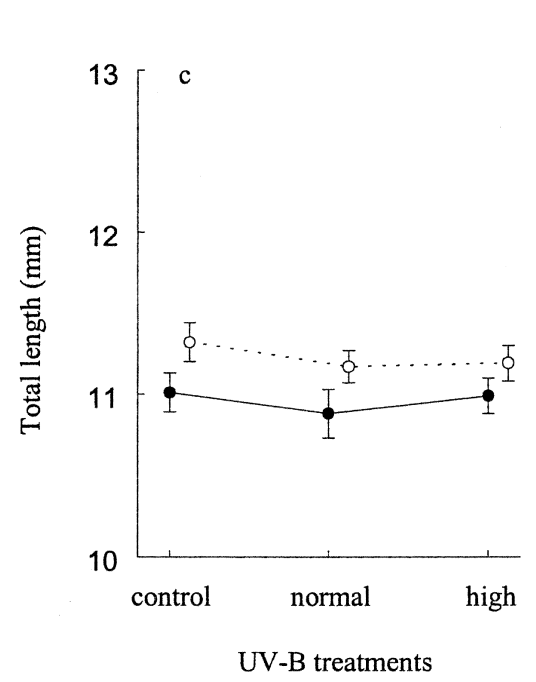

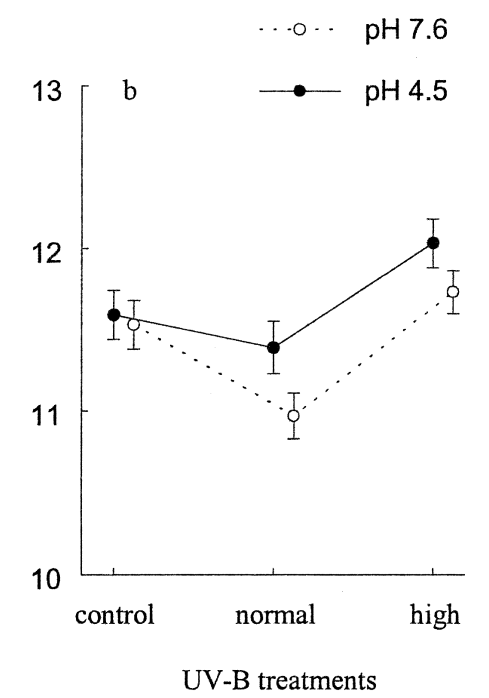

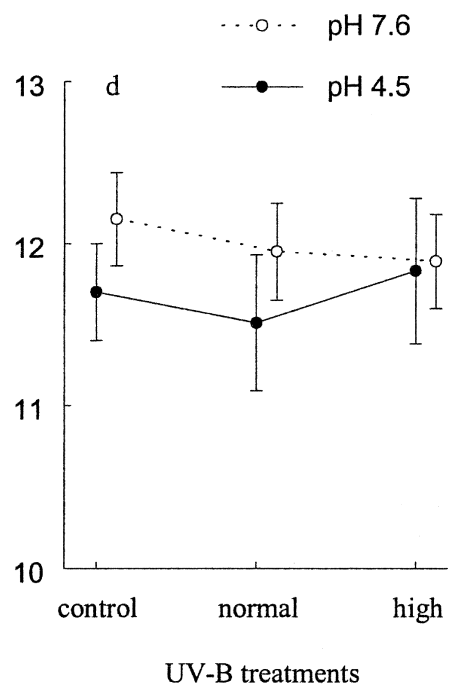

Figure 2. Developmental time and batchling size in Rana temporaria in different $U V-B$ and $p H$ treatments: (a) developmental time among southern and (b) northern embryos and batchling size of (c) southern and (d) northern larvae. Values are least square means ( $\pm S E$ ) from models presented in Tables 3 and 4. ever, a significant population $\times \mathrm{pH}$ interaction $\left(F_{1,208}=\right.$ 9.63, $p=0.0022$ ) revealed that the effect of low $\mathrm{pH}$ was more pronounced in the northern population (Fig. $2 \mathrm{a}$ \& 2b).

\section{Hatchling Size}

As in the case of development time, the response of average hatchling size to UV-B and $\mathrm{pH}$ treatments was similar in both populations: low $\mathrm{pH}$ reduced average hatchling size in all UV-B treatments and the embryos from the control UV-B and neutral $\mathrm{pH}$ treatment hatched at larger size than those from normal and high treatments (Table 4; Fig. 2c \& 2d). The effects of UV-B treatment were significant only in the southern population (Table 4), however, and there was no evidence for synergism between UV-B and $\mathrm{pH}$ in either of the popula- tions (Table 4). Combined analysis of the two populations revealed significant overall effects of UV-B $\left(F_{2,180}=\right.$ $3.56, p=0.03)$ and $\mathrm{pH}\left(F_{1,180}=39.98, p<0.001\right)$ on average hatchling size, but there was no evidence of population differences in responses to either of the stressors.

\section{Discussion}

Our results demonstrate lethal and sublethal effects of UV-B radiation on embryonic performance-survival, frequency of developmental anomalies, size at hatching, and development time- of $R$. temporaria. These findings appear to conflict with previous evidence suggesting that UV-B radiation does not have negative effects on embryonic survival or the frequency of developmental 
Table 3. Mixed-model nested analysis of variance of developmental time in response to UV-B and pH treatments in two Rana temporaria populations.*

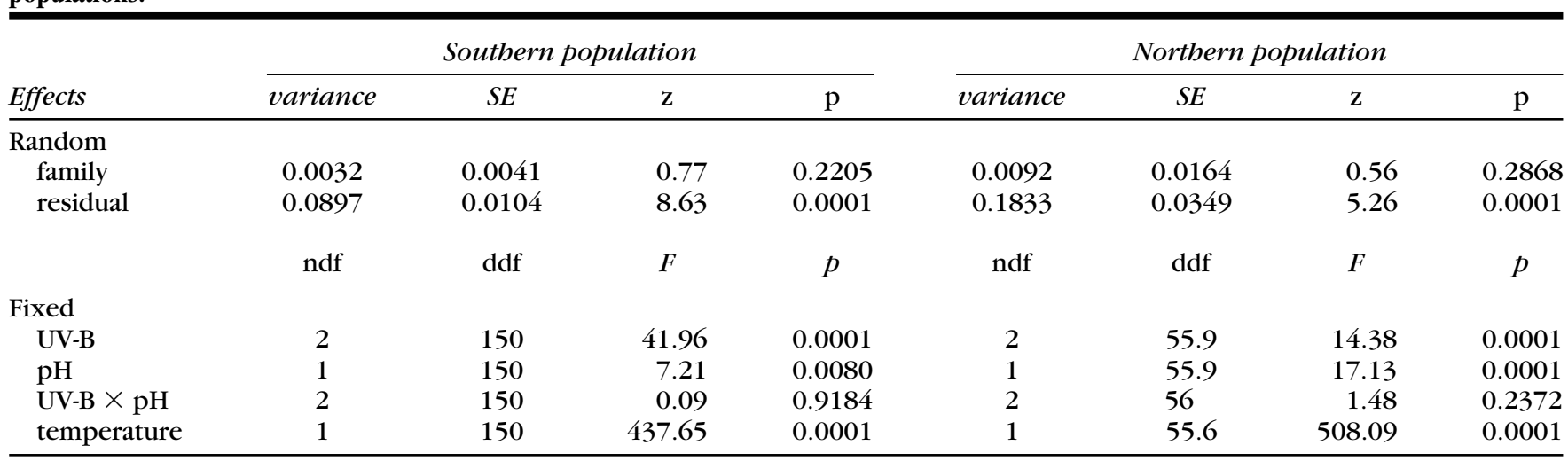

*Abbreviations: ndf, numerator degrees of freedom; ddf, denominator degrees of freedom.

anomalies in this species (Cummins et al. 1999; Langhelle et al. 1999; Hofer \& Mokri 2000; Merilä et al. 2000a; Pahkala et al. 2000, 2001). Our results suggest, however, that the negative effects of UV-B radiation may be highly population-specific and confined to particular, stressful environmental conditions. We observed the negative effects of UV-B on survival in only one of the two populations and only at low $\mathrm{pH}$. The same applied to the frequency of developmental anomalies, although low $\mathrm{pH}$, in combination with a normal UV-B regime, also seemed to increase their frequency in the southern population. These findings provide further evidence for the contention that different populations of the same species may differ in their sensitivity to UV-B radiation (Williamson et al. 1997; Corn 1998; Belden et al. 2000) and that the synergism between UV-B radiation and other stressors may magnify the negative effects of UV-B radiation on amphibian development (Kiesecker \& Blaustein 1995; Long et al. 1995; Ankley et al. 1998; Hatch \& Burton 1998; Walker et al. 1998; Zaga et al. 1998; Monson et al. 1999; Hatch \& Blaustein 2000). Consequently, conclusions based on tests of UV-B radiation tolerance using single populations in the absence of other relevant environmental stressors should be viewed with caution.

Embryos from the northern population were more sensitive to UV-B radiation than those from the south. This is surprising in view of the fact that our UV-B treatments simulating normal and high UV-B radiation levels were based on radiation levels representative of those experienced by Uppsala frogs (approximately $59^{\circ} \mathrm{N}$ ). Because radiation levels during the breeding season of $R$. temporaria increase toward the north (Josefsson \& Karlsson 1997; Merilä et al. 2000b), the doses experienced by the southern embryos in the normal UV-B treatment are likely to be somewhat higher than they would normally experience, whereas the opposite would be true in the case of the northern embryos. However, one potential explanation for these results resides in the differential sensitivity of the populations to low $\mathrm{pH}$. The environment of southern Sweden has experienced heavy acidification since the early eighteenth century (Bergkvist 1995), and earlier work on amphibians from this area suggests that populations suffering the effects of acidification might have evolved tolerance to low $\mathrm{pH}$

Table 4. Mixed-model nested analysis of variance of the hatchling size in response to UV-B and pH treatments in two Rana temporaria populations.*

\begin{tabular}{|c|c|c|c|c|c|c|c|c|}
\hline \multirow{3}{*}{$\begin{array}{l}\text { Random } \\
\text { family } \\
\text { residual }\end{array}$} & & & & & & & & \\
\hline & 0.0508 & 0.0064 & 7.79 & 0.0001 & 0.1651 & 0.0324 & 5.10 & 0.0001 \\
\hline & ndf & ddf & $F$ & $p$ & ndf & ddf & $F$ & $p$ \\
\hline UV-B & 2 & 127 & 3.90 & 0.0227 & 2 & 52 & 0.76 & 0.4722 \\
\hline $\mathrm{pH}$ & 1 & 127 & 44.14 & 0.0001 & 1 & 52 & 9.35 & 0.0035 \\
\hline $\mathrm{UV}-\mathrm{B} \times \mathrm{pH}$ & 2 & 127 & 0.65 & 0.5255 & 2 & 52 & 1.74 & 0.1848 \\
\hline temperature & 1 & 127 & 0.29 & 0.5901 & 1 & 52 & 1.29 & 0.2606 \\
\hline
\end{tabular}

*Abbreviations: ndf, numerator degrees of freedom; ddf, denominator degrees of freedom. 
(Andrén et al. 1989). Against this background, the better tolerance of the southern embryos over those from north may not be that surprising.

The development times of embryos in both populations and in both $\mathrm{pH}$ treatments were consistently shorter under normal than under high and control UV-B radiation treatments. It is known that UV-B irradiation has positive effects in biological systems, such as stimulation of vitamin (Garman et al. 2000) and pigment synthesis (Stiffler 1993; Cockell \& Knowland 1999), and there might be an adaptive optimum at intermediate doses of UV-B for these processes to take place. The faster development of embryos under a normal UV-B regime may also represent an adaptive response to avoid prolonged exposure to UV-B radiation. Such a response might not be possible under higher levels of UV-B, however, due, for example, to some trade-off between energy or resources allocated to the development and protection of physiological machinery from UV-B-induced photoproducts (Epel et al. 1999; Pahkala et al. 2000). Further studies of this issue are needed, but the explanations we present are consistent with the contention that rapid development and growth is expected to evolve to minimize the amount of time an organism spends in a vulnerable stage of development (Arendt 1997). However, such responses may be constrained by extreme levels of stress (Hoffmann \& Parsons 1997).

In the southern population, hatchling size tended to be larger in control than in normal and high UV-B treatments. This result provides further support for the earlier finding that UV-B radiation may have a negative effect on the growth of amphibian embryos and larvae (Grant \& Licht 1995; Bruggeman et al. 1998; Belden et al. 2000; Pahkala et al. 2000; Smith et al. 2000; Pahkala et al. 2001). Similar negative effects of UV-B radiation on growth have been observed in plants (e.g., Sullivan et al. 1992; Johanson et al. 1995; Nielsen et al. 1995). One potential explanation for these observations could be the possible trade-off between the energy allocated to growth and mechanisms protecting organisms from the negative effects of UV-B radiation. The lack of further reduction in hatchling size in high UV-B treatment, compared with normal UV-B treatment, is not in conflict with this explanation because the larvae in the high UV-B treatment had significantly longer development times than those in the normal UV-B treatment. Hence, whatever the proximate causes, the fact that hatchling size is an important fitness correlate in amphibians (Kaplan 1982, 1998; Semlitsch \& Schmiedehausen 1994) suggests that UV-B radiation may have negative effects on the later fitness of $R$. temporaria individuals. To this end, it is worth stressing that some of the negative effects of embryonic exposure to UV-B radiation could become expressed only at the later developmental stages (Smith et al. 2000; Pahkala et al. 2001), and further studies are required to assess the occurrence of such delayed effects.
Our results suggest that different populations of the same species may differ in their tolerance to UV-B radiation and, consequently, in their vulnerability to the projected increases in levels of UV-B radiation. Our results further suggest that, especially in regions where acid pollution is a concern, the synergistic effects of UV-B and low $\mathrm{pH}$ may have negative effects on amphibian populations. Likewise, even if UV-B radiation does not cause severe mortality in $R$. temporaria embryos, sublethal effects through inhibited growth may have effects on future fitness.

\section{Acknowledgments}

We thank F. Söderman, M. Ylianttila, K. Thuman, N. Persson, M. Ekström, and A. Timenes Laugen for help with the field and laboratory work and T. Jones for editing our English. Comments by two anonymous reviewers improved an earlier draft of the paper. This study was financially supported by the Swedish Natural Science Research Council, the Swedish Agriculture and Forestry Research Council, the Academy of Finland and Maj, and Tor Nessling Foundation (Finland).

\section{Literature Cited}

Arctic Monitoring Assessment Program (AMAP). 1998. Acidifying pollutants, arctic haze, and acidification in the Arctic. Assessment report. Pages 612-659 in Arctic pollution issues. AMAP, Oslo, Norway.

Alford, R. A., and S. J. Richards. 1999. Global amphibian declines: a problem in applied ecology. Annual Review of Ecology and Systematics 30:133-165.

American Public Health Association (APHA). 1985. Standard methods for the examination of water and wastewater. 16th edition. APHA, Washington, D.C.

Andrén, C., M. M. Marden, and G. Nilsson. 1989. Tolerance to low pH in a population of moor frogs, Rana arvalis, from acid and a neutral environments: a possible case of rapid evolutionary response to acidification. Oikos 56:215-223.

Ankley, G. T., D. L. DeFoe, K. M. Jensen, G. W. Holcombe, E. J. Durhan, and S. A. Diamond. 1998. Effects of ultraviolet light and methoprene on survival and development of Rana pipiens. Environmental Toxicology and Chemistry 17:2530-2542.

Anzalone, C. R., L. B. Kats, and M. Gordon. 1998. Effects of solar UV-B radiation on embryonic development in Hyla cadaverina, Hyla regilla, and Taricha torosa. Conservation Biology 12:646-653.

Arendt, J. D. 1997. Adaptive intrinsic growth rates: an integration across taxa. Quarterly Review of Biology 72:149-177.

Aston, R. J., R. C. Beattie, and A. G. P. Milner. 1987. Characteristics of spawning sites of the common frog (Rana temporaria) with particular reference to acidity. Journal of Zoology 213:233-242.

Beattie, R. C., R. Tyler-Jones, and M. J. Baxter. 1992. The effects of pH, aluminium concentration and temperature on the embryonic development of the European common frog, Rana temporaria. Journal of Zoology 228:557-570.

Beebee, T. J. C. 1983. Habitat selection by amphibians across an agricultural land-heathland transect in Britain. Biological Conservation 27:111-124

Belden, L. K., E. L. Wildy, and A. R. Blaustein. 2000. Growth, survival 
and behaviour of larval long-toed salamanders (Ambystoma macrodactylum) exposed to ambient levels of UV-B radiation. Journal of Zoology 251:473-479.

Berger, L., M. Rybacki, and H. Hotz. 1994. Artificial fertilization of water frogs. Amphibia-Reptilia 15:108-113.

Bergkvist, B. 1995. Försurningen har trängt djupt ner i skogsmarken. Pages 19-34 in Försurningen i Sverige: vad vet vi egentligen? Rapport 4421. Naturvårdsvärket, Solna, Sweden.

Berven, K. A. 1990. Factors affecting population fluctuations in larval and adult stages of the wood frog (Rana sylvatica). Ecology 71: 1599-1608.

Björn, L. O., and T. M. Murphy. 1985. Computer calculations of solar ultraviolet radiation at ground level. Physiologie Végétale 23:555-561.

Björn, L. O., and A. H. Teramura. 1993. Simulation of daylight ultraviolet radiation and effects of ozone depletion. Pages 41-71 in R. A. Young, L. O. Björn, J. Moan, and W. Nultsch, editors. Environmental UV photobiology. Plenum Press, New York.

Blaustein, A. R., P. D. Hoffman, D. G. Hokit, J. M. Kiesecker, S. C. Walls, and J. B. Hays. 1994. UV repair and resistance to solar UV-B in amphibian eggs: a link to population declines. Proceeding of the National Academy of Sciences of the United States of America 91: 1791-1795.

Blaustein, A. R., J. M. Kiesecker, D. P. Chivers, D. G. Hokit, A. Marco, L. K. Belden, and A. Hatch. 1998. Effects of ultraviolet radiation on amphibians: field experiments. American Zoologist 38:799-812.

Blaustein, A. R., J. B. Hays, P. D. Hoffman, D. P. Chivers, J. M. Kiesecker, W. P. Leonard, A. Marco, D. H. Olson, J. K. Reaser, and R. G. Anthony. 1999. DNA repair and resistance to UV-B radiation in western spotted frogs. Ecolological Applications 9:1100-1105.

Blaustein, A. R., D. P. Chivers, L. B. Kats, and J. M. Kiesecker. 2000. Effects of ultraviolet radiation on locomotion and orientation in roughskin newts (Taricha granulosa). Ethology 106:227-234.

Brodin, Y. W. 1993. Acidification: an everlasting problem, or is there hope? Page 50. The environment in Sweden: status trends. Swedish Environmental Protection Agency, Värnamo, Sweden.

Broomhall, S. D., W. S. Osborne, and R. B. Cunningham. 2000. Comparative effects of ambient ultraviolet-B radiation on two sympatric species of Australian frogs. Conservation Biology 14:420-427.

Bruggeman, D. J., J. A. Bantle, and C. Goad. 1998. Linking teratogenesis, growth, and DNA photodamage to artificial ultraviolet B radiation in Xenopus laevis larvae. Environmental Toxicology and Chemistry 17:2114-2121.

Caldwell, J. P., J. H. Thorp, and T. O. Jervey. 1980. Predator-prey relationship among larval dragonflies, salamanders, and frogs. Oecologia 46:285-289.

Cockell, C. S., and J. Knowland. 1999. Ultraviolet radiation screening compounds. Biological Review 74:311-345.

Corn, P. S. 1998. Effects of ultraviolet radiation on boreal toads in Colorado. Ecological Applications 8:18-26.

Cummins, C. P., P. D. Greenslade, and A. R. McLeod. 1999. A test of the effect of supplemental UV-B radiation on the common frog, Rana temporaria L., during embryonic development. Global Change Biology 5:471-479.

Epel, D., K. Hemela, M. Shick, and C. Patton. 1999. Development in the floating world: defenses of eggs and embryos against damage from UV radiation. American Zoologist 39:271-278.

Garman, E. N., G. W. Ferguson, W. H. Gehrmann, T. C. Chen, and M. F. Holick. 2000. Photobiosynthetic opportunity and ability for UV-B generated vitamin D synthesis in free-living house geckos (Hemidactylus turcicus) and Texas spiny lizards (Sceloporus olivaceous). Copeia 2000:245-250.

Gasc, J. P., A. Cabela, J. Crnobrnja-Isailovic, D. Dolmen, K. Grossenbacher, P. Haffner, J. Lescure, H. Martens, J. P. Martinéz Rica, M. E. Oliveira, T. S. Sofianidou, M. Veith, and A. Zuiderwijk. 1997. Atlas of amphibians and reptiles in Europe. Societas Europaea Herpetologica and Muséum National d'Histoire Naturelle (IEGB/SPN), Paris.
Gosner, K. L. 1960. A simplified table for staging anuran embryos and larvae with notes on identification. Copeia 1960:183-190.

Grant, K. P., and L. E. Licht. 1995. Effects of ultraviolet radiation on life-history stages of anurans from Ontario, Canada. Canadian Journal of Zoology 73:2292-2301.

Hatch, A. C., and G. A. Burton Jr. 1998. Effects of photoinduced toxicity of fluoranthene on amphibian embryos and larvae. Environmental Toxicology and Chemistry 17:1777-1785.

Hatch, A. C., and A. R. Blaustein. 2000. Combined effects of UV-B, nitrate, and low $\mathrm{pH}$ reduce the survival and activity level of larvae cascades frogs (Rana cascadae). Archives of Environmental Contamination and Toxicology 39:494-499.

Hofer, R., and C. Mokri. 2000. Photoprotection in tadpoles of the common frog, Rana temporaria. Journal of Photochemistry and Photobiology B: Biology 59:48-53.

Hoffmann, A. A, and P. A. Parsons. 1997. Evolutionary genetics and environmental stress. Oxford University Press, Oxford, United Kingdom.

Houlahan, J. E, C. S. Findlay, B. R. Schmidt, A. H. Meyer, and S. L. Kuzmin. 2000. Quantitative evidence for global amphibian population declines. Nature 404:752-755.

Howard, R. D. 1980. Mating behaviour and mating success in wood frogs, Rana sylvatica. Animal Behaviour 28:705-716.

Johanson, U., C. Gehrke, L. O. Björn, and T. V. Callaghan. 1995. The effects of enhanced UV-B radiation on the growth of dwarf shrubs in a subarctic heathland. Functional Ecology 9:713-719.

Josefsson, W., and J. E. Karlsson. 1997. Measurements of total ozone 1994-1996. Report 79. Swedish Meteorological and Hydrological Institute, Meteorology and Climatology, Reports Meteorology and Climatology (RMK), Norrköping, Sweden.

Kaplan, R. H. 1982. Greater maternal investments can decrease offspring survival in Bombina orientalis. Ecology 73:280-288.

Kaplan, R. H. 1998. Maternal effects, developmental plasticity and life history evolution: an amphibian model. Pages 244-260 in T.H. Mousseau and C.W. Fox, editors. Maternal effects as adaptations. Oxford University Press, New York.

Kaplan, R. H., and S. N. Salthe. 1979. The allometry of reproduction: an empirical view in salamanders. The American Naturalist 113:671-689.

Kats, L. B., J. M. Kiesecker, D. P. Chivers, and A. R. Blaustein. 2000. Effects of UV-B radiation on anti-predator behavior in three species of amphibians. Ethology 106:921-931.

Kiesecker, J. M., and A. R. Blaustein. 1995. Synergism between UV-B radiation and a pathogen magnifies amphibian embryo mortality in nature. Proceedings of the National Academy of Sciences of the United States of America 92:11049-11052.

Kiesecker, J. M., A. R. Blaustein, and L. K. Belden. 2001. Complex causes of amphibian population declines. Nature 410:681-683.

Langhelle, A., M. J. Lindell, and P. Nyström. 1999. Effects of ultraviolet radiation on amphibian embryonic and larval development. Journal of Herpetology 33:449-456.

Laurila, A. 1998. Breeding habitat selection and larval performance of two anurans in freshwater rock-pools. Ecography 21:484-494.

Laurila, A., and P. Seppä. 1998. Multiple paternity in the common frog Rana temporaria: genetic evidence from tadpole kin groups. Biological Journal of the Linnean Society 63:221-232.

Lean, D. R. 1998. Influence of UVB radiation on aquatic ecosystems. Pages 1-20 in E. E. Little, A. J. DeLonay, and B. M. Greenberg, editors. Environmental and toxicology and risk assessment. Volume 7. ASTM STP 1333. American Society for Testing Materials, Philadelphia.

Leuven, R. S. E. W., C. den Hartog, M. M. C. Christiaans, and W. H. C. Heijligers. 1986. Effects of water acidification on the distribution pattern and the reproductive success of amphibians. Experientia 42:495-503.

Littell, R. C., G. A. Milliken, W. W. Stroup, and R. D. Wolfinger. 1996. SAS system for mixed models. SAS Institute, Cary, North Carolina.

Lizana, M., and E. M. Pedraza. 1999. Effects of UV-B radiation on toad mortality in montanious areas of central Spain. Conservation Biology 13:703-707. 
Long, L. E., L. S. Saylor, and M. E. Soulé. 1995. A pH/UV-B synergism in amphibians. Conservation Biology 9:1301-1303.

Merilä, J., A. Laurila, and M. Pahkala. 2000 $a$. Effects of ambient UV-B radiation on early development of the common frog (Rana temporaria) embryos in the subarctic. Annales Zoologici Fennici 37:51-58.

Merilä, J., M. Pahkala, and U. Johansson. 2000b. A frog perspective on increased ultraviolet-B radiation, climate change and latitudinal adaptation. Annales Zoologici Fennici 37:129-134.

Monson, P. D., D. J. Call, D. A. Dean, A. Cox, K. Liber, and G. T. Ankley. 1999. Photoinduced toxicity of fluoranthene to northern leopard frogs (Rana pipiens). Environmental Toxicology and Chemistry 18:308-312.

Nielsen, T., L. O. Björn, and G. A. Ekelund. 1995. Impact of natural and artificial UV-B radiation on motility and growth rate of marine dinoflagellates. Journal of Photochemistry and Photobiology 27: 73-79.

Ovaska, K., T. M. Davis, and I. N. Flamarique. 1997. Hatching success and larval survival of the frogs Hyla regilla and Rana aurora under ambient and artificially enhanced solar ultraviolet radiation. Canadian Journal of Zoology 75:1081-1088.

Pahkala, M., A. Laurila, and J. Merilä. 2000. Ambient ultraviolet-B radiation reduces hatchling size in the common frog Rana temporaria. Ecography 23:531-538.

Pahkala, M., A. Laurila, and J. Merilä. 2001. Carry-over effects of UV-B radiation on larval fitness in Rana temporaria. Proceedings of the Royal Society of London, Series B 268:1699-1706.

Pechmann, J. H. K., and H. M. Wilbur. 1994. Putting declining amphibian populations in perspective: natural fluctuations and human impacts. Herpetologica 50:65-84.

Pechmann, J. H. K., D. E. Scott, R. D. Semlitsch, J. P. Caldwell, L. J. Vitt, and J. Whitfield Gibbons. 1991. Declining amphibian populations: the problem of separating human impacts from natural fluctuations. Science 253:892-895.

SAS Institute. 1996. SAS. SAS Institute, Cary, North Carolina.

Schindler, D. W., P. Jefferson Curtis, B. R. Parker, and M. P. Stainton. 1996. Consequences of climatic warming and lake acidification for UV-B penetration in North American lakes. Nature 379:705-708.

Semlitsch, R. D., and S. Schmiedehausen. 1994. Paternal contributions to variation in hatchling size and its relationship to growth and metamorphosis in tadpoles of Rana lessonae and Rana esculenta. Copeia 1994:406-412.

Semlitsch, R. D., D. E. Scott, and J. H. K. Pechmann. 1988. Time and size at metamorphosis related to adult fitness in Ambystoma talpoideum. Ecology 71:1789-1795.

Smith, D. C. 1987. Adult recruitment in chorus frogs: effects of size and date at metamorphosis. Ecology 68:344-350.

Smith, G. R., M. A. Waters, and J. E. Rettig. 2000. Consequences of embryonic UV-B exposure for embryos and tadpoles of the plains leopard frog. Conservation Biology 14:1903-1907.

Steinwascher, K. 1979. Competitive interactions among tadpoles: responses to resource levels. Ecology 60:1172-1183.

Stiffler, D. F. 1993. Amphibian calcium metabolism. Journal of Experimental Biology 184:47-61.

Strijbosch, H. 1979. Habitat selection of amphibians during their aquatic phase. Oikos 33:363-372.

Sullivan, J. H., A. H. Teramura, and L. H. Ziska. 1992. Variation in UV-B sensitivity in plants from a 3,000-m elevational gradient in Hawaii. American Journal of Botany 79:737-743.

Travis, J. 1984. Anuran size at metamorphosis: experimental test of a model based on intraspecific competition. Ecology 65:1155-1160.

Wake, D. B. 1991. Declining amphibian populations. Science 253:860.

Walker, S. E., D. H. Taylor, and J. T. Oris. 1998. Behavioral and histopathological effects of fluoranthene on bullfrog larvae (Rana catesbeiana). Environmental Toxicology and Chemistry 17:734-739.

Wilbur, H. M., P. J. Morin, and R. N. Harris. 1983. Salamander predation and the structure of experimental communities: anuran responses. Ecology 64:1423-1429.

Williamson, C. E., S. L. Metzgar, P. A. Lovera, and R. E. Moeller. 1997. Solar ultraviolet radiation and the spawning habitat of yellow perch, Perca flavescens. Ecological Applications 7:1017-1023.

Worrest, R. C., and D. J. Kimeldorf. 1975. Photoreactivation of potentially lethal, UV-induced damage to boreal toad (Bufo boreas boreas) tadpoles. Life Sciences 17:1545-1550.

Worrest, R. C., and D. J. Kimeldorf. 1976. Distortions in amphibian development induced by ultraviolet-B enhancement (290-315 nm) of a simulated solar spectrum. Photochemistry and Photobiology 24: 377-382.

Zaga, A., E. E. Little, C. F. Rabeni, and M. R. Ellersieck. 1998. Photoenhanced toxicity of a carbamate incesticide to early life stage anuran amphibians. Environmental Toxicology and Chemistry 17:2543-2553.

Zar, J. H. 1996. Biostatistical analysis. 3rd edition. Prentice hall, Upper Saddle River, New Jersey.

Zhao, X., and D. Mu. 1998. (6-4) photolyase: light-dependent repair of DNA damage. Histology and Histopathology 13:1179-1182.
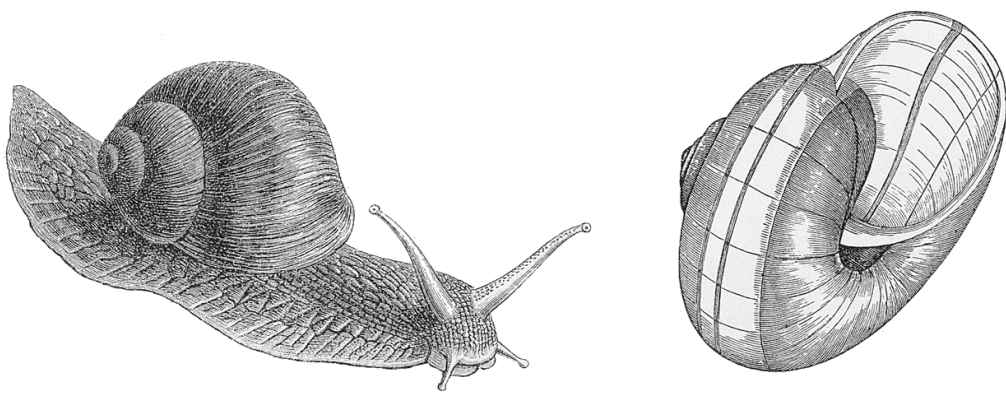